\title{
PEMBERIAN REBUSAN DAUN KATUK PADA IBU MENYUSUI DALAM UPAYA PENINGKATAN PRODUKSI ASI DI PMB ERNITA AMD.KEB PEKANBARU TAHUN 2019
}

\author{
Riza Febrianti ${ }^{1)}$ Intan Widya Sari ${ }^{2)}$ \\ STIKes Hang Tuah Pekanbaru ${ }^{1)}$ \\ Email : rizafebrianti77@yahoo.com
}

\begin{abstract}
Breastfeeding is a natural process. Nursingis not only for the purpose of feeding the baby but also for the forming of an inner relationship between mothet and child. Exlusive breast feeding in indonesia at only 35\%. That figure is still well under $50 \%$ of the world health organization, which is one reason why breast-feeding is u derproduction. Efforts being made to increase breast-feeding in the mother's feeding system by consuming the cascading water of the katuk leaves home become well-known for improving breast milk as it contains galactagogue, which is fueling the increase in breast milk production. In this case the author feeds on suckling mom with a meansure of boiled chiseled whater of 90 grams of casctares and $450 \mathrm{ml}$ of boiled water up to 15 minutes and then consumed by nursing $150 \mathrm{ml}$ by three meals a day for 14 days this was taken three visits. Lividity spent of Mrs.S 31 years old witha shortage of breast milk. After an inbreeding program with 14 days of boiled castle-leaf water, the result was increased breast milk production in the mother. As a place of health care should be in PMB ernita encourages lactating mothers to use boiled casctle-leaf water to boost breast-feeding production.
\end{abstract}

Keywords : Katuk Leaf, Breastfeeding Mother, Breast Milk Production

\begin{abstract}
ABSTRAK
Menyusui merupakan proses yang alami. Menyusui bukan hanya bertujuan untuk memberikan makanan kepada bayi, tetapi juga untuk menjalin hubungan bathin antara ibu dan anak. pemberian ASI ekslusif di indonesia hanya 35\%. Angka tersebut masih jauh dibawah rekomendasi WHO (Badan Kesehatan Dunia) sebesar 50\%,salah satu alasan nya yaitu karna produksi ASI yang kurang. Upaya yang dilakukan untuk meningkatkan produksi ASI pada ibu menyusui yaitu dengan mengkonsumsi rebusan air daun katuk, daun katuk telah terkenal dalam hal peningkatan ASI karena mengandung galactagogue yang memicu peningkatan produksi ASI. Dalam kasus ini penulis melakukan asuhan kebidanan pada ibu menyusui dengan takaran untuk rebusan air daun katuk yaitu 90 gram daun katuk dan $450 \mathrm{ml}$ air direbus hingga 15 menit lalu dikonsumsi oleh ibu menyusui 150ml dengan 3 kali minum dalam sehari selama 14 hari asuhan agar produksi ASI optimal dan juga melakukan asuhan secara menyeluruh dan berkesinambungan melalui metode pendokumentasian S-O-A-P. Pengambilan kasus ini dilakukan dengan 3 kali kunjungan. Asuhan kebidanan dengan pemberian rebusan air daun katuk dilakukan pada Ny.S usia 31 tahun dengan kurangnya produksi ASI. Setelah dilakukan asuhan kebidanan dengan mengkonsumsi rebusan air daun katuk selama 14 hari, didapatkan hasil adanya peningkatan produksi ASI pada ibu. Sebagai tempat pelayanan kesehatan hendaknya di PMB Ernita menganjurkan pada ibu menyusui untuk mengkonsumsi rebusan air daun katuk untuk meningkatkan produksi ASI

Kata Kunci : Daun Katuk, Ibu Menyusui, Produksi Asi
\end{abstract}




\section{PENDAHULUAN}

Menyusui merupakan proses yang alami. Menyusui sebenarnya tidak hanya bertujuan untuk memberikan makanan kepada bayi,tetapi juga menjalin hubungan bathin antara ibu dan anak. Hal ini sangat penting untuk perkembangan psikologis dan emosional anak. Bagi ibu menyusui juga menguntungkan karna dapat mempercepat pengecilan rahim menjarangkan kehamilan juga dapat mengurangi resiko penyakit kanker payudara dan kanker rahim (Suhartika \& Djamilus, 2015).

\section{World Health Organization} (WHO) merekomendasikan pemberian ASI Ekslusif sekurang-kurangnya 6 bulan pertama kehidupan dan dilanjutkan dengan makanan pendamping sampai usia 2 tahun. American Academy of Pediatrcs (AAP), Academy of Breastfeeding Mdice (ABM) dan ikatan dokter indonesia

(IDAI) merekomendasikan hal yang sama tentang pemberian ASI ekslusif sekurangkurangnya 6 bulan. Berdasarkan data UNICEF Sebanyak 136,7 juta bayi lahir diseluruh dunia dan hanya $32,6 \%$ dari mereka yang disusui secara ekslusif dalam 6 bulan pertama.,sementara di negara berkemang hanya 39\% ibu-ibu yang memberikan ASI Ekslusif (Rizki Ramadhan, 2015).
Angka pemberian ASI ekslusif di indonesia masih tergolong rendah. Menurut pusat data dan Informasi kementrian kesehatan 2017, pemberian ASI ekslusif di indonesia hanya $35 \%$. Angka tersebut masih jauh dibawah rekomendasi WHO (Badan Kesehatan Dunia) sebesar 50\% (Astuti,I. 2018). Sedangkan di provinsi riau tahun 2017 pencapaian ASI ekslusif $69,4 \%$ (Nislawati,2018).

Salah satu upaya yang dapat dilakukan untuk meningkatkan sekresi dan produksi ASI adalah melalui penggunaan obat ramuan tradisional seperti daun katuk (sauropus androgynus). Daun katuk ternyata telah dikenal dalam pengobatan penambah ASI. Daun katuk dapat dikonsumsi dengan mudah, serta dapat di rebus dan di produksi sebagai fitofarmaka yang berkhasiat untuk melancarkan ASI (Juliastuti, 2019).

Asuhan yang dapat diberikan pada ibu menyusui yaitu dengan cara pemberian rebusan air daun katuk. Rebusan daun air katuk yang akan diberikan kepada ibu menyusui diambil 90 gram daun katuk kemudian direbus dengan air sebanyak 450ml atau (2 gelas setengah gelas belimbing) selama 15 menit (hingga daun katuk matang/lunak) kemudian disaring. Air rebusannya yang akan diminum oleh ibu tiga kali $150 \mathrm{ml}$ 
sehari. Dan ini dilakukan selama 14 hari. (Situmorang, 2019).

\section{METODE PENERAPAN}

Metode penelitian ini dilaksanakan dalam bentuk Penyuluhan dan Metode demonstrasi terhadap pemberian rebusan daun katuk pada ibu menyusui dengan menerapkan langsung setelah diberikan penyuluhan

\section{HASIL DAN PEMBAHASAN}

\section{A. HASIL PELAKSANAAN}

Kegiatan penelitian telah dilaksanakan pada tanggal 22 Agustus 2019 sebanyak 2 orang di PMB Ernita Kota Pekanbaru. Berdasarkan wawancara, tanya jawab dan pengamatan langsung selama kegiatan penelitian ini memberikan hasil berikut :

1. Meningkatnya pengetahuan dan pemahaman ibu-ibu tentang pemberian rebsan daun katuk pada ibu menyusui.

2. Ibu dapat mempraktikkan merebus daun katuk. Hal ini dilihat dari kemampuan ibu dalam menjawab pertanyaan yang diajukan oleh pemateri dan kesedian ibu menyusui.

\section{B. PEMBAHASAN}

Kegiatan penyuluhan dan praktik cara merebus daun katuk yang dilaksanakan di PMB Ernita Kota Pekanbaru berjalan dengan baik dan sesuai rencana. Hal ini terbukti antusiasme para peserta saat mengikuti jalanya kegiatan. Para peserta penyuluhan benar-benar memperhatikan dan mendengarkan dengan baik penyuluhan dan praktik yang disampaikan.

\section{KESIMPULAN}

Rebusan daun katuk di gunakan untuk memproduksi asi pada ibu menyusui mengetahui cara dan manfaatnya daun katuk, serta dapat menjelaskan kembali mengenai daun katuk. Selain bermanfaat untuk menambah air susu ibu selaama menyusui,.

\section{DAFTAR PUSTAKA}

Astutik, Y. (2015). asuhan kebidanan pada ibu nifas dan menyusui. gosyen publishing.

Herawati, Y., \& Desriyeni. (2017). Kemas Ulang Informasi Manfaat Daun Katuk Untuk Produksi Air Susu Ibu (ASI). Jurnal Ilmu 
Informasi Perpustakaan Dan

Kearsipan, 6(1), 78-85.

Juliastuti, J. (2019). Efektivitas Daun Katuk (Sauropus Androgynus)

Terhadap Kecukupan Asi Pada Ibu
Menyusui Di Puskesmas Kuta Baro Aceh Besar. Indonesian Journal for Health Sciences, 3(1), 1. https://doi.org/10.24269/ijhs.v3i1.16 00. 